\title{
Involvement and Image Transfer in Sports Sponsorship
}

\author{
Manuel Alonso-Dos-Santos ${ }^{1}$, Jolita Vveinhardt ${ }^{2}$, Ferran Calabuig-Moreno ${ }^{3}$, Francisco. J. Montoro-Rios ${ }^{4}$ \\ ${ }^{1}$ Universidad Catolica de la Santisima Concepcion \\ Av. Alonso de Ribera 2850, 4090541, Concepcion, Chile \\ E-mail.malonso@ucsc.cl \\ ${ }^{2}$ Lithuanian Sports University \\ Sporto st. 6, LT-44221 Kaunas, Lithuania \\ E-mail.jolitaw@gmail.com \\ ${ }^{3}$ University of Valencia \\ C / Gasco Oliag 3, E-46010 Valencia, Spain \\ E-mail.ferran.calabuig@uv.es \\ ${ }^{4}$ University of Granada \\ Campus de Cartuja, E-18071 Granada, Spain \\ E-mail.fmontoro@ugr.es \\ cross $^{\text {ref }}$ http://dx.doi.org/10.5755/j01.ee.27.1.8536
}

Sponsorships have become one of the most important marketing tools. Data show that a majority of sporting events is sponsored and that investment in sponsorship is increasing every year. Companies are demanding more research to better understand their investment efficacy. Involvement is a key element in processing sponsorship information in consumers' minds. This variable affects consumer behavior and moderates the sponsor image transfer. The study of involvement could give guidance for the design of appropriate and functional advertising campaigns. The research proposes segmenting and modelling sport consumer behaviour in sponsorship by their level of involvement with the event. For this task, we propose a model for image transfer between the sponsored entity and the sponsor. Using Finite Mix Partial Least Square methods, two sample segments are achieved. The data were obtained with a web banner during an international tennis event. In conclusion, the least involved individuals do not process the image transfer effect, as opposed to the individuals who are more involved. In the theoretical field, this paper is the first to include segmentation by Finite Mix in sponsorship research. Finally, attraction and involvement strategies are proposed based on the characteristics for each of the variables in this model, for example, regular meetings for fans, autograph signings and weekly chat sessions on the web site. This study provides guidance for companies about how to increase their customers' willingness to purchase, how to improve their image, how to increase supporters' involvement and finally, how to design effective communication for supporters according to their level of involvement.

Keywords: Sport, Event, PLS, Consumer Involvement, Sponsorship.

\section{Introduction}

Corporations are carefully examining their sponsorship investments, making it necessary to offer knowledge and methodologies for evaluating the effectiveness of sponsorship activities (Kim, Ko, \& James, 2011). Sponsorship is one of the marketing strategies most commonly used (Maxwell \& Lough, 2009) as well as the most relevant (Olson, 2010). The majority of sporting events are sponsored in some way (Mazodier \& Quester, 2014). In 2013 corporations invested 53.1 billion dollars worldwide in sport sponsorships (IEG, 2014). Two thirds of sponsorship expenses are allocated to backing sports teams, events, and players (Chao, 2011). It can be a successful long-term strategy for companies (Farrelly \& Quester, 2005). More and more viewers and sports fans follow sporting events, and their level of involvement may even lead them to travel internationally to support and follow their athletes and teams (Davies \& Williment, 2008).
Sports sponsorship is a strategic tool that was born in the sixties. Despite its history, today there is a lack of research in the area (Novais \& Arcodia, 2013), making it academically interesting. It is also important to business and the economy because of the large investments made, the complexity of its operations, its strategic nature, the importance over other communication technologies, and the growing interest of companies for social responsibility (Pappu \& Cornwell, 2014).

In regard to sponsorship's effects, the literature review (Novais \& Arcodia, 2013; Dees, Bennett, \& Villegas, 2008; Meenaghan, 2001) shows that the sponsorship's main results are: profitability of the sponsor's image, the transmission of the image, consumer response, generation of awareness and perception of widespread use.

In order to achieve maximum effectiveness in patronage, several stages of research have been identified by the scientific literature (Meenaghan, 2001): (1) categorizing sponsorship activities, (2) measuring effects of sponsorship, (3) understanding consumer response in 
terms of demographic and psychographic variables such as age, gender or athletic participation, and (4) studying the cognitive and affective processes that occur in the minds of consumers.

To deal with this last category, the authors have based their arguments on theories explaining the process of image transmission. A previous study of the following theories will allow for a better understanding of the process of image transmission: the mere exposure theory (Gail, Nelson, Srzentic, \& King, 2007), the balance theory (Heider, 1958), the affective transfer model (Pracejus, 2004), the signalling theory (Kim \& Choi, 2007), the attribution theory (Rifon, Choi, Trimble, \& Li, 2004), the social alliance theory (Madrigal, 2001), the social comparison theory (Abrahams \& Hogg, 2012), the psychological conditioning model (Tribou, 2011), the elaboration likelihood model (Petty \& Cacioppo, 1984), and the multi-attribute attitude model (Bettman, Capon, \& Lutz, 1975). Finally, the image transfer theory (Gwinner, 1997) would allow us to measure the effectiveness of sponsorship in order to increase the purchase intention of the sponsor's products.

Different variables influencing the process of image transmission have been previously identified. In this way, Grohs and Reisinger (2014) argue that there is still confusion regarding several important components of consumer response to sponsorship, including involvement. In addition to involvement, congruence (Osgood \& Tannenbaum, 1955) is a very important factor, yet only some of its operation is understood (Macdougall, Nguyen, \& Karg, 2014). Image transfer in sport sponsorship is a current issue because of economic and academic reasons (Lobo, Meyer, \& Chester, 2014; Macdougall et al., 2014; Mazodier \& Quester, 2014; Pappu \& Cornwell, 2014). In spite of its young age (Gwinner, 1997; Gwinner \& Eaton, 1999), its important role has been validated through several empirical studies (Alexandris \& Tsiotsou, 2012a). Nevertheless, a number of theoretical reviews have shown the need for more and better knowledge in this field (Novais \& Arcodia, 2013). Sponsorship efficacy is still under consideration in some aspects, including: the role of the event size, image transfer moderators, differences between sporting disciplines, and why and when the sponsor image does not transfer to the sponsored event.

This study provides empirical knowledge about sponsorship efficacy in medium sized events, using segmentation variables to explain why the message processing is different depending on the individuals' characteristics.

During this study, a model of image transmission in sponsorship is constructed to measure intention to purchase the sponsor's products. Congruence is used as an influencing variable and involvement as a segmentation variable. A new segmentation technique based on nonparametric assumption, never before used in this area, is employed in this study, Finite Mixture Partial Least Squares (FIMIX-PLS).

Relevance of the research: Although other authors have recently examined the effect of sport sponsorships (Alexandris \& Tsiotsou, 2012b), this research considers the involvement variable for modelling the sport consumer behaviour and segments the sample with a method never used in the past in this field of research, FIMIX-PLS. Only a few studies in the area of sponsorship have examined the purchasing intent of sports consumers, which is the objective of selling corporate sponsorships (Kim et al., 2011). According to Dilys and Gargasas (2014) sponsors and sports organizations needed to cooperate more; therefore the results of this study are geared towards both the sponsoring corporations and sports event organizations from a theoretical and practical standpoint to achieve mutual benefits. In practice, this study will allow both, sponsors and sponsored organizations to implement more effective marketing tools, designing specific messages for specific segments of consumers, meeting their particular interests.

Object of the research: the sponsoring process in the context of a sporting event.

Aim of the research: To analyze the image transfer process in sports sponsorship in order to go into detail about the involvement's moderation role on advertising efficacy, as well as its potential as a segmentation variable. To achieve this aim, the following tasks of the research are set:

1. Discuss the previous research on sponsoring and its relationship with image transfer, congruence and involvement.

2. Empirically assess the measurement model and the structural model.

Problem of the research: companies involved in sports sponsorship need to know their return of investment. This study examines how involvement influences information processing, and willingness to buy the sponsor's brands. To do that, we use the image transfer model applied to the sponsorship.

Methods of the research: quantitative data analysis obtained through a questionnaire.

\section{Influence Variables and Hypotheses Presentation}

\section{Image transfer in sport sponsorship}

The term image transfer is used in marketing literature and sports sponsorship to indicate the sequence by which a sponsor benefits from the inherent attributes of a sporting event. The study of image transfer has been approached from different theories, for example, the mere exposure theory, the affective transfer model, the signalling theory, or the social alliance theory. However, three theories have dominated the rest when explaining the influence of the event's image on sponsorship (Grohs \& Reisinger, 2014). First, the classical conditioning theory, which comes from advertising research and was used to examine the results on consumers' attitudes while they were exposed to sponsorship stimulus (Speed \& Thompson, 2000). Second, the meaning transfer model (McCracken, 1989), which suggests that the cultural significance of a symbol may be associated with a brand with a particular meaning. Finally, the image transfer theory (Gwinner, 1997), which allows us to measure sponsorship effectiveness levels to increase sponsor product purchase intentions. Using image transfer theory as a reference, sporting teams and events have personality and attributes associated with their brand. Individual sporting events are associated with certain characteristics (Meenaghan, 1983). When an activity is 
sponsored, pictures are transferred to the sponsor, then the attitude one has towards the sponsored event is transferred to the sponsor (Grohs, Wagner, \& Vsetecka, 2004; Gwinner, 1997; Gwinner \& Eaton, 1999; Meenaghan, 2001), just as with brand equity in other areas of marketing (Cornwell \& Maignan, 1998).

In sporting events, it occurs when the brand is associated with the event, and the characteristics associated to the event are transferred to the brand. This association occurs when an individual connects information in regards to the event's attributes, benefits, and attitudes in his memory and transfers them to the brand (Dees et al., 2008; Keller, 2003; Lardinoit \& Quester, 2001; Levin, Joiner, \& Cameron, 2001; Meenaghan, 2001). Keller (2003) defines the attitude towards the sponsor as the overall evaluation towards the brand and organization. Others see it as a bias towards the brand by consumers (Meenaghan, 2001). What is certain is that this variable has been one of the means most used to measure the effectiveness of sponsorship (Kim et al., 2011).

For example, Formula 1 is associated with speed, power and precision. Brand product categories such as computers and watches could be interested in positioning their brands based on these characteristics. The transfer is achieved simultaneously by presenting both brands (Grohs \& Reisinger, 2005). Several studies have provided empirical evidence supporting the theory of image transfer for sporting events (Grohs et al., 2004).

Different authors have used consumers' attitudes towards the brand involved in the sponsorship as a measure of the effectiveness of a marketing campaign (Farrelly, Quester, \& Burton, 2006; Lacey, Close, \& Finney, 2010; Mohr \& Webb, 2005; Roy, 2011). For example, Levin et al. (2001) adopted the variable attitude towards the sponsor to prove the effect of exposure time in sponsorship recall. Roy and Cornwell (2004) used the same measure to evaluate the effect of brand equity in response to the sponsored event. Purchasing intent is considered to be the appropriate indicator to measure sponsorship effectiveness (Ko, Kim, Claussen, \& Kim, 2008). Additionally, the influence that attitude has on intention has been recognized as the final step in the process of image transfer (Cornwell \& Coote, 2005; Lacey, Sneath, Finney, \& Close, 2007; Pope \& Voges, 2000; Quester \& Farrelly, 1998). Therefore, the following hypotheses are proposed, both of which represent the backbone of the image transfer process:

H1: Attitudes towards the sponsored event have a positive influence on the attitudes towards the sponsor.

$\mathrm{H} 2$ : Attitudes towards the sponsor positively influence the intention to purchase the sponsor's products.

The theoretical model of image transfer, proposed by Gwinner (1997) recognizes that the spectator's congruence and involvement with the event can influence the image transfer process. Thereby, Grohs (2015) affirms that the fit between sponsor and sponsored directly influences the sponsor's image. Regarding the implication, Grohs confirms that the literature has yet to determine its exact influence and depth, and that the moderating effect that implication has on the general process of the transmission of the attitude on the intention of purchase is unknown (Novais \& Arcodia, 2013). In response, we used the image transfer theory to study in depth how congruence and implication influence the sponsorship process.

Congruence. It measures the 'adjustment' or 'fit' between sponsor and sponsored, according to consumer perceptions (Rifon et al., 2004). It is the perception of parallelism between both of them (Clark, Cornwell, \& Pruitt, 2009), taking into account their relationship (Johan \& Pham, 1999) or compatibility (Ruth \& Simonin, 2003).

Research on advertising has been taken into consideration in the field of sports sponsorship, with the objective of explaining perception's influence on the fitting relationship between sponsor and sponsored. For example, Jagre, Watson, and Watson (2001), suggest that a better fit can influence the sponsor's results, based on the theory of congruence applied to advertising. This concept of coherence has been subsequently applied within the theory of integrated communication of marketing, showing its effectiveness on the attitude towards the brand (NavarroBailon, 2012).

Advertising efficacy in the framework of sports sponsorship has been studied for more than ten years, especially its influence on brand recall (Wakefield, Becker-Olsen, \& Cornwell, 2007), sponsor awareness (Grohs \& Reisinger, 2005), corporate social responsibility (Pappu \& Cornwell, 2014) and image transfer (Meenaghan, 2001). It has even been analyzed from a dynamic point of view (Woisetschläger \& Michaelis, 2012) and from the supporters perspective and their relationship with the club (Johnston \& Paulsen, 2011).

The perception of congruence between the sponsor and the sports event is based on their logical relationship and connection. This relationship permits the transfer of the event's image to the sponsor, and vice versa. Therefore, the consumer is able to easily store information about products, due to the link produced between the sponsored event and the brand (Chao, 2011).

The more prominent effects are related to the transfer of image and attitude. Thus, it is proposed that congruence generates a transfer of attitude from the sponsored toward the sponsor (Pappu \& Cornwell, 2014). Gwinner and Eaton (1999) state that there is a transfer of image as well. Meenaghan (2001) adds that incongruency would decrease that transfer of image. So sponsors could improve their image and sponsorship efficacy if they use the appropriate associations.

Some theories have been formulated to explain the main principles of the congruence joint (McDaniel, 1999; Rifon et al., 2004; Rodgers, 2004). However all of them have established a theoretical framework to reduce cognitive dissonance in the evaluation of the sponsorship relationships (Macdougall, Nguyen, \& Karg, 2014). Therefore, evaluation of the congruence between the sponsor and the specific characteristics of the event could provide information related to the consumer perception of the sponsored brands as well as to serve as a measure of its efficacy.

Studies argue that a more coherent sponsorship results in a more effective sponsorship. Previous research estimates that the positive congruence significantly influences the sponsorship's effectiveness (Drengner, Jahn, \& Zanger, 2011; Johnston \& Paulsen, 2011; Roy, 2010; Wang, Cheng, Purwanto, \& Erimurti, 2011), therefore: 
H3: The fit perceived by the consumer between the sponsor and the sponsored event has a positive influence on the attitudes towards the sponsor.

Involvement. Once the image transfer model and the most important influence variables identified in the marketing literature have been established, it is necessary to determine the moderating effect of involvement.

There is no single definition of involvement. But many authors do relate involvement with the importance or interest that an object has for one person. Some authors define involvement as the individual's perceived relevance of an object based on needs, values, and interests in the sports marketing field (Beaton, Funk, Ridinger, \& Jordan, 2011; Bennett, Ferreira, Lee, \& Polite, 2009; Hur, Ko, \& Claussen, 2012; Ko, Kim, Kim, \& Lee, 2010; Stevens \& Rosenberger, 2012). Involvement varies according to the individual characteristics, situational factors, and the characteristics of the product or stimulus (Zaichkowsky, 1985). It is a useful concept for understanding the behaviour of sports fans and their attitudes (Stevens \& Rosenberger, 2012).

In order to understand the concept of implication and its influence on image transfer in sponsorship, different authors have turned to the Elaboration Likelihood Model (ELM) (Petty, Cacioppo, \& Schumann, 1983). For example, Mazodier and Quester, (2014) suggested that highly involved people may be more motivated to process incongruity. Or, as Keller (1993) indicates, attitudes may be formed by making less reflexive decisions, in other words, more involved individuals process information by the outlying route, more emotional. In any case, ELM serves as a theoretical support to the moderating effect that implication has on the image transfer model, as will be explained further on.

Involvement has great importance and consequences because consumers that are more involved (Llorens, 2011), look for more external information prior to and post purchase, use a more complex decision making process, engage in attendance at events, test new models and have interest in the product category, are more interested in advertising, find more fun in buying, are more likely to become opinion leaders, are more committed to the brand, frequently use the product and often tend to buy more, are more loyal to the brand, have a better memory, are more likely to value the benefits of relationship marketing tactics and respond positively to them, and play an important role in the product's adoption process. More importantly, fans who are involved with the sporting event are more likely to respond positively to the sponsorship activities (Speed \& Thompson, 2000).

In the context of sports, highly involved consumers are more likely to pay close attention and exert more effort in processing information (Flynn \& Goldsmith, 1993). Sports enthusiasts with high involvement levels are prone to be more committed and active with the search for information about their favourite club or sports discipline, and want to share these experiences with others (Alexandris \& Tsiotsou, 2012a). The latter characteristic implies that more involved supporters are more active in social networks (Alonso Dos Santos, 2014). Pritchard, Funk, and Alexandris (2009) found that the most involved baseball enthusiasts are more prone to use a variety of media to be informed about scores, news and analyses. This is relevant because a higher involvement implies a higher exposure to commercial activities.

Shank and Beasley (1998) discovered that when involvement is high, the consumer makes a greater cognitive effort to process information (central route). When involvement is low, the consumer depends more on affective signals when evaluating the message. According to Petty and Cacioppo (1984), in the persuasion process, the involvement will be more or less influential depending on the effort made by the individual to process the information received. Thus, people process the message differently depending on, among other variables, their personal involvement with the message, the product or the buying decision. Personal involvement is the major determinant of the likelihood that the consumer processes the message (Funk, Ridinger, \& Moorman, 2004; Grohs \& Reisinger, 2014). Thus the measurement of consumer involvement becomes a key aspect in order to increase the advertising efficiency.

Previous research suggests that involvement has an effect on attitudes, image transfer process and congruence (Mazodier \& Quester, 2014; Olson, 2010). For example, Martensen, Grønholdt, Bendtsen, and Jensen, (2007) suggest that the sports fan who is more involved, develops a better attitude towards the sponsor's brand. Grohs and Reisinger (2014) found a moderation effect on congruence and sponsors image. Thus, the following hypothesis is proposed:

H4: The more involved consumers process the sponsor's message in a significant way, unlike less involved individuals.

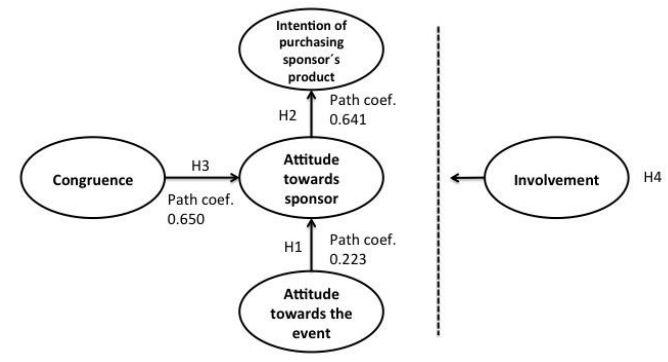

Figure 1. Image transfer model

\section{Methodology}

To start collecting data, a banner was introduced on the website of a tennis event, Valencia Open 500, which redirected the user to an online self-administered survey with a Likert type scale. Other studies have used a similar methodology (for example: Alonso Dos Santos, Calabuig, Montoro-Rios, Valantine, \& Emeljanovas, 2014; Woisetschläger \& Michaelis, 2012). The event's official website is considered an appropriate means for sample recruitment since all of the information related to the event (athletes, tickets sale, scores, and forums and social networks) is included on it. Other studies have used this procedure (Eagleman \& Krohn, 2012). Thus, we used a non probability sampling technique with a convenience sampling approach, similar to previous studies on the topic (Grohs \& Reisinger, 2014; Hutabarat \& Gayatri, 2014). A convenience sampling method was used, given the absence of an adequate sampling frame. In sporting events that are 
marketed to spectators (as opposed to participatory events, such as marathons), there is no known population base of spectators or followers that would permit carrying out probabilistic sampling techniques. Therefore it is common to use convenience samples in these types of studies (Mazodier \& Merunka, 2012).

Valencia Open 500 is a professional tennis tournament, which takes place every year in Valencia, Spain. It is included in the calendar of the Association of Tennis Professionals (ATP). In 2013 it received more than 900 hours of television broadcasting. It had over 65 million TV viewers worldwide.

Scales. The scales used for data collection were adapted from relevant academic sources. The scale to measure the attitude towards the sponsor was adapted from Dees et al. (2008), and the congruence scale from Roy (2011) and Speed and Thompson (2000). The attitudes towards the event scale was adjusted from Speed and Thompson (2000) and the purchasing intent from Smith, Graetz, and Westerbeek (2008).

PLS Methodology. The method of analysis chosen for this research is Partial Least Square (PLS). It is a modelling method of structural equations with SmartPLS (Ringle, Wende, \& Will, 2005). PLS is essentially a regression analysis (Hair, Ringle, \& Sarstedt, 2011), appropriate when examining a series of constructs and their relations with dependent variables and each other (Chin, 1998a). PLS is appropriate for this study because it can handle the constructs with only a few indicator elements (Hair, Sarstedt, Ringle, \& Mena, 2011). It is also less restrictive in the assumptions regarding data normal data distribution (Hair et al., 2011). It is also appropriate when the sample sizes are small (Chin, Marcolin, \& Newsted, 2003). Other studies in sports marketing have used PLS to test hypotheses (Alonso Dos Santos et al., 2014; Howat \& Assaker, 2013) and it has been shown to be a valid method in exploratory studies (Goodhue, Lewis, \& Thompson, 2012; Henseler \& Chin, 2010). Validation of the measurement model, evaluation of the structural model, as well as the test of hypotheses has been done using the procedure proposed by Vinzi, Chin, Henseler, \& Wang (2010).

\section{Results}

Data treatment. First, the missing values were treated by using the Listwise method. To treat outlier values, a Mahalanobis (1936) analysis was performed. A sample of 259 cases from 301 completed surveys was obtained. A normality analysis revealed a structure that was neither univariant nor multivariant. The sample was composed of a total of 144 males (55.6\% of the sample). The most frequent age range was 25-34 years old (27.8\%), followed by $18-24$ and $44-54$ years old, (16.2\% each). $11 \%$ of the individuals had attended the event five times or more, 20.4 $\%$ of the sample had never attended this event, while $52 \%$ of the sample had attended once or twice. The average item score was between a minimum of 3.76 (purchasing intent) and a maximum of 4.33 (attitude towards the event). Standard deviation was between a minimum of 0.8 (attitude towards the event) and a maximum of 1 (purchasing intent).
Evaluation of the measurement model. The evaluation of individual reliability was done by examining the standardized load or outer loadings, which exceeded the minimum value of 0.6 (Barclay, Higgins, \& Thompson, 1995) (Table 1). The composite reliability (CR) is used to measure the scale's reliability. The values obtained exceeded the recommended threshold of 0.7 (Nunnally, 2010). Regarding convergent validity, the average variance extracted (AVE) is examined, which exceeded the value of 0.5 (Fornell \& Larcker, 1981).

The evaluation of discriminant validity was satisfied by (a) an analysis of the average variance shared between the construct and its measures (Barclay et al., 1995) and (b) the correlations between the construct and the square root of the AVE (Fornell \& Larcker, 1981).

Structural model evaluation. The evaluation of the structural model is analysed using the squared multiple correlation coefficient (R2). All the values meet the minimum of 0.1 proposed by Falk and Miller (1992) (Table 1).

Table 1

\begin{tabular}{|c|c|c|c|c|c|c|}
\hline \multicolumn{7}{|c|}{ Measurement and structural models analysis } \\
\hline Construct & $\begin{array}{l}\text { Factor } \\
\text { loadings }\end{array}$ & $\mathrm{CR}$ & Cronbach & AVE & $\mathrm{R} 2$ & $\begin{array}{l}\text { Effect } \\
\text { sizef2 } \\
\text { Cohen }\end{array}$ \\
\hline \multicolumn{7}{|l|}{ Attitude } \\
\hline $\begin{array}{l}\text { towards the } \\
\text { event }\end{array}$ & & 0.933 & 0.823 & 0.874 & - & - \\
\hline ATTEVE1 & 0.920 & & & & & \\
\hline ATTEVE2 & 0.928 & & & & & \\
\hline \\
\hline $\begin{array}{l}\text { towards the } \\
\text { sponsor }\end{array}$ & & 0.933 & 0.877 & 0.823 & 0.647 & 0.547 \\
\hline ATTSP1 & 0.884 & & & & & \\
\hline ATTSP2 & 0.918 & & & & & \\
\hline ATTSP3 & 0.884 & & & & & \\
\hline Congruence & & 0.937 & 0.881 & 0.834 & - & - \\
\hline CONGRU1 & 0.913 & & & & & \\
\hline CONGRU2 & 0.910 & & & & & \\
\hline CONGRU3 & 0.872 & & & & & \\
\hline \multicolumn{7}{|l|}{ Purchasing } \\
\hline intent & & 0.900 & 0.814 & 0.751 & 0.610 & 0.369 \\
\hline PURINT1 & 0.823 & & & & & \\
\hline PURINT2 & 0.850 & & & & & \\
\hline PURINT3 & 0.886 & & & & & \\
\hline
\end{tabular}

According to Chin (1998b), the standardized path coefficients are considered significant if they reach a value of at least 0.2 , therefore all are significant (Figure 1). They are also economically relevant as all the values obtained exceeded the recommended value. PLS's bootstrap procedure assigns $t$ values to the estimated regression parameters, allowing identification of significant relationships between variables. Thus, in order to test the Hypotheses 1, 2 and 3, an examination of p-values is needed (Figure 1). All hypotheses are supported with a pvalue below 0.05 .

The Stone-Geisser test (Q2) is used for the analysis of predictive relevance. According to Chin (1998b), the coefficient should have a positive value. The value of the statistic is 0.281 , thus the model has predictive relevance.

In addition, the goodness of fit (GoF) is defined as the measure indicating how well a specified model reproduces the covariance matrix among the indicator variables (Hair et al., 2011). The value is 0.646 . The index ranges between 
0 and 1 (Tenenhaus, Esposito Vinzi, Chatelin, \& Lauro, 2005). A GoF greater than 0.61 is considered large (Wetzels, Odekerken-Schröder, \& van Oppen, 2009).

Segmentation and sub-sample analysis. Two methods are used to segment the sample: A cluster analysis and a segmentation FIMIX-PLS. Hahn, Johnson, Herrmann, and Huber, (2002) introduced the FIMIX-PLS technique for the detection of latent segments. The method identifies the latent classes in the model without establishing a classification in advance. Simulation studies (Sarstedt \& Ringle, 2010) stress the positive results with this approach when compared with alternative segmentation methods. We followed the methodological approach proposed by Sarstedt, Becker, Ringle, and Schwaiger (2011) and Sarstedt and Ringle (2010) for segmentation purposes.

First, a cluster analysis is performed using the Ward method to identify the consumers with different levels of involvement with the event. Two sub-samples are obtained; they are identified as group 1 and group 2. Group 1 is described as "individuals with low levels of involvement", while group 2 is characterized as "individuals with medium and high levels of involvement" according to the involvement scores.

An analysis of variance (ANOVA) is used to determine if there are significant differences between these two groups. Group one is comprised of 45 individuals, 17
$\%$ of the sample, and group 2 has a total of 214 individuals, or $82 \%$.

The value of Normalized Entropy coefficient (NE) (Ramaswamy DeSarbo, Reibstein, \& Robinson, 1993) is higher for two segments, thus confirming the results of the cluster method. Then, a multi-group analysis is performed using the procedure of random assignment or permutation (Chin \& Dibbern, 2010). The permutation procedure is more common in significance testing for non-normal data between groups. The next step is performing an individual analysis for both segments. Regarding main effect of image transfer through sponsorship (attitude towards the event to attitude towards the sponsor), for the less involved consumer group the significance coefficient is below 1.96, or not significant, which indicates that for less involved consumer group the image transfer does not occur (Table 2).

The relationship between the attitude towards the sponsor and purchase intention is not significantly different between groups, because the attitude towards the sponsor positively influences the purchasing intent, regardless of the level of involvement with the event. The relationship between congruence and attitude towards the sponsor is significantly different between groups, but both groups suggest a positive and significant relationship.

Hypotheses test and multi-group analysis for involvement with the event

\begin{tabular}{|c|c|c|c|c|c|}
\hline & Difference & P-value & Significant & Group1 & Group 2 \\
\hline ATTEVE -> ATTSPO & 0.21 & 0.029 & Yes & 1.236 & 2.279 \\
\hline ATTSPO -> PURINT & 0.15 & 0.040 & No & 7.346 & 7.859 \\
\hline CONGRU -> ATTSPO & 0.16 & 0.099 & Yes & 5.890 & 8.609 \\
\hline
\end{tabular}

However, the regression coefficient is significantly different between groups regarding the relationship of attitude towards the event and attitude towards the sponsor. Rerunning the model with different groups shows that the effect is stronger in individuals with higher involvement levels. The relationship between attitude towards the event and attitude towards the sponsor in the less involved group is not significant.

To summarize the previous process, first two groups of individuals have been identified. Second, the model has been tested for both groups, finding significant differences between them in the way they process the sponsorship information. Third, a separate analysis has been implemented in each group (table 2) finding a lack of image transfer in the case of those with low involvement, thus supporting hypothesis $\mathrm{H} 4$.

\section{Discussion and Conclusions}

Discussion. The aim of this study was to evaluate the effect consumer involvement has on image transfer in sponsorship. A model was built to meet this objective. Image transmission was measured through attitude. The final outcome is to measure purchase intention of the sponsor's products. The congruence variable is included in the model because of the importance described in the literature.
Using the PLS method, the validity and reliability of the measurement scale was confirmed and the proposed hypotheses were tested and accepted. Subsequently, a segmentation of the sample was done to determine whether involvement levels could moderate the effect of image transfer. As the assumptions are accepted, it is appropriate to initiate the discussion.

Image transfer does occur. Hypotheses H1 is accepted. It supports the investment by corporations for increasing visibility and brand awareness, in addition to improving attitudes towards the brand by extracting and assimilating values inherent to the sponsored event or the sport. Hypotheses $\mathrm{H} 2$ is accepted as well. Although in general researchers lack control mechanisms to isolate the direct relationship between the sponsorship and sales performance (Quester \& Farrelly, 1998), sports organizations should research how to improve attitudes towards their brand through sponsorships in order to increase revenue. Among the suggested strategies, Sutton, McDonald, Milne, and Cimperman (1997) propose making the event more accessible to the fan, increasing community involvement, and reinforcing history and traditions associated with the event.

Hypothesis $\mathrm{H} 3$ is supported. The congruence has a positive effect on the attitude toward the sponsor. The main conclusion is that corporate sponsors should choose more congruent sponsorships. Incongruent sponsorships need more financial resources to achieve the same results 
as congruent sponsorships (Tribou, 2011). Spectators try to assimilate the incongruity of the sponsorship as they confront it. It is not congruent that a fast food company or an alcoholic beverage sponsor sporting events, but repetitive exposure measured by the exposure to the spectators, means that the consumer will develop a better fit. These results support the idea of Poon and Prendergast (2006), who suggest that the fit influences the consumer's cognitive and affective responses as well as the conative process. Therefore, the more congruent sponsorship should be the ones selected.

Conclusions. Consumers process the effect of the sponsorship differently depending on their level of involvement with the event. Image transfer does occur for the consumers with higher levels of involvement, but it does not arise with low levels of involvement.

The relationship between attitudes towards the sponsor and purchasing intent was not significantly different between groups of involvement level. In other words, attitudes towards the sponsor positively influence purchasing intent regardless of the level of consumer involvement with the event. Similarly, the congruence indicates differences between groups. But for both groups the congruence influences the attitude towards the sponsor.

The difference between involvement groups in the relationship of the attitude towards the event and attitude towards the sponsor is significant. The group with a low level of involvement showed no significant relationship between attitudes towards the event and attitudes towards the sponsor. Thus, image transfer from the event to sponsor does not appear. In the group with high levels of involvement, the relationship was significant and the image transfer from the event to the sponsor does occur. Therefore, it is recommended to segment the consumers by level of involvement and develop strategies aimed at increasing consumer involvement on the less involved consumers. These actions are aimed at promoting a more effective image transfer process, which will ultimately result in economic benefits for the organization through the sponsorship process.

Dale, van Iwaarden, van der Wiele, and Williams (2005) suggest that a pricing strategy can be used to encourage consumers with higher involvement levels. For the less involved fans, an economic offer would not be as attractive because they are more motivated by the entertainment opportunity (Mahony, Madrigal, \& Howard, 2000).

In conclusion, it is advisable to increase consumer involvement through various strategies, for example, the development and implementation of a website (Hur et al., 2012; Scholl \& Carlson, 2012) and implementing more effective CSR activities (Blumrodt, Bryson, \& Flanagan, 2012; Pharr \& Lough, 2012; Roy, 2011). Similarly, it would be appropriate, according to Stevens and Rosenberger (2012), to generate interest in the outcome of the game by using similar level players, as well as observing and implementing communication strategies capable of generating wider coverage by the media. The organization may take actions aimed at increasing sport fan involvement, such as regular fan meetings, autograph sessions, and weekly chat sessions on their website, as well as taking advantage of social media as communication channels with the fans, the novel consumer and the organization. In general, it is recommended to provide opportunities of interaction with consumers before, during, and after the event (Beaton et al., 2011). On the other hand, raffles and contests can be implemented positioning the brand at the event location and through the media.

To conclude, results support the key role of involvement. Moreover, results provide means to segment the consumers and formulate efficient marketing strategies. Consumers with higher levels of involvement are more profitable, opinion leaders, and heavy buyers with better responses to promotional activities. On the other hand, involvement is a viable criterion in order to segment the market. Thus segmenting the market in terms of consumer involvement with the event, and designing the appropriate marketing campaigns for involved consumers, will increase the efficiency and ROI of marketing campaigns.

\section{Limitations and Future Lines of Research}

First, one should be cautious in extrapolating the results to sports organizations in general, even to different types of sports. This study was carried out within a particular sports discipline that represents specific values. The method used to administer the survey may have influenced the characteristic of the sample; the respondents may have specific characteristics attributable to online users. However, the website is, in many cases, the only way for fans to gather accurate information about the event. In addition, the sample is small, although it is large enough for the method employed (PLS). A problem with the use of partial least squares is that observed variables can contain measurement errors, which can produce inconsistent estimators (Henseler \& Chin, 2010). However, some authors argue that the PLS technique is much more similar to regression than covariance-based structural equation modeling (CB-SEM) techniques (Goodhue et al., 2012). In regards to the characteristics of the sample, the results indicate that a high percentage of the sample elements were drawn from the community where the event was organized.

The following are proposed as future lines of research: Perform a longitudinal analysis on the same sample in order to study the effects of possible sponsor changes. Study the image transfer from sponsor to sponsored event: in other words, study how the choice of sponsor influences the attitudes towards the event, organization or towards the athletes. Analyze how past experiences with other sporting events can influence the attitudes towards the target sport event as well as towards the sponsors. Finally, it would be interesting to address the effectiveness of sponsorship and image transfer from an emotional standpoint. While cognition is indeed relevant for a successful sponsorship, it seems necessary to research the role of consumer emotional response when determining the properties of the results of sponsorship due to the emotional response that sports teams and events generate in the consumer and the viewer (Bal, Quester, \& Plewa 2009). 


\section{References}

Abrams, D., \& Hogg, M. A. (2012). Social identifications: A social psychology of intergroup relations and group processes. London, UK: Routledge.

Alexandris, K., \& Tsiotsou, R. H. (2012a). Segmenting soccer spectators by attachment levels: a psychographic profile based on team self-expression and involvement. European Sport Management Quarterly, 12(1), 65-81. http://dx.doi.org/10.1080/16184742.2011.637174

Alexandris, K., Tsiotsou, R. H., \& James, J. D. (2012b). Testing a hierarchy of effects model of sponsorship effectiveness. Journal of Sport Management, 26(5), 363-378

Alonso Dos Santos, M. (2014). Sport Marketing: Cyber Strategies for Clubs and Events. In A. Ghorbani (Ed.), Marketing in the Cyber Era: Strategies and Emerging Trends (pp. 177-189). Hershey, PA: Business Science Reference. http://dx.doi.org/10.4018/978-1-4666-4864-7.ch012

Alonso Dos Santos, M., Calabuig, F., Montoro, F., Valantine, I., \& Emeljanovas, A. (2014). Destination image of a city hosting sport event: Effect on sponsorship. Transformations in Business \& Economics, 13(2A), 343-360.

Bal, C., Quester, P., \& Plewa, C. (2009). Event-related emotions: A key metric to assess sponsorship effectiveness. Journal of Sponsorship, 2(4), 367-378.

Barclay, D., Higgins, C., \& Thompson, R. (1995). The partial least squares (PLS) approach to causal modeling: Personal computer adoption and use as an illustration. Technology Studies, 2(2), 285-309.

Beaton, A. A., Funk, D. C., Ridinger, L., \& Jordan, J. (2011). Sport involvement: A conceptual and empirical analysis. Sport Management Review, 14(2), 126-140. http://dx.doi.org/10.1016/j.smr.2010.07.002

Bennett, G., Ferreira, M., Lee, J., \& Polite, F. (2009). The role of involvement in sports and sport spectatorship in sponsor's brand use: The case of mountain dew and action sports sponsorship. Sport Marketing Quarterly, 18(1), 14-24.

Bettman, J. R., Capon, N., \& Lutz, R. J. (1975). Multiattribute measurement models and multiattribute attitude theory: A test of construct validity. Journal of Consumer Research, 1(4), 1-15.

Blumrodt, J., Bryson, D., \& Flanagan, J. (2012). European football teams' CSR engagement impacts on customer-based brand equity. Journal of Consumer Marketing, 29(7), 482-493. http://dx.doi.org/10.1108/07363761211274992

Chao, W. C. (2011). Sports sponsorship effects: The role of logo visual fluency, familiarity, and sponsor-event congruence for audience recall of team sponsors (M.A.). Michigan State University.

Chin, W. W. (1998a). Issues and opinion on structural equation modeling. MIS Quarterly, 22(1), 1-10.

Chin, W. W. (1998b). The partial least squares approach to structural equation modeling. In G. A. Marcoulides (Ed.), Modern Methods for Business Research (pp. 295-336). New Jersey, USA: Lawrence Erlbaum Associates.

Chin, W. W., \& Dibbern, J. (2010). An introduction to a permutation based procedure for multi-group PLS analysis: Results of tests of differences on simulated data and a cross cultural analysis of the sourcing of information system services between Germany and the USA. In E. V. Vinzi, W. W. Chin, J. Henseler, \& H. Wang (Eds.), Handbook of Partial Least Squares. Berlin, Germany: Springer-Verlag.

Chin, W. W., Marcolin, B. L., \& Newsted, P. R. (2003). A partial least squares latent variable modeling approach for measuring interaction effects: Results from a Monte Carlo simulation study and an electronic-mail emotion/adoption study. Information Systems Research, 14(2), 189-217.

Clark, J., Cornwell, T. B., \& Pruitt, S. (2009). The impact of title event sponsorship announcements on shareholder wealth. Marketing Letters, 20(2), 169-182. http://dx.doi.org/10.1007/s11002-008-9064-z

Cornwell, T. B., \& Coote, L. V. (2005). Corporate sponsorship of a cause: The role of identification in purchase intent. Journal of Business Research, 58(3), 268-276. http://dx.doi.org/10.1016/S0148-2963(03)00135-8

Cornwell, T. B., \& Maignan, I. (1998). An international review of sponsorship research. Journal of Advertising, 27(1), 121. http://dx.doi.org/10.1080/00913367.1998.10673539

Dale, B., Van Iwaarden, J., Van der Wiele, T., \& Williams, R. (2005). Service improvement in a sports environment: A study of spectator attendance. Managing Service Quality, 15(5), 470-484. http://dx.doi.org/10.1108/0960452051 0617310

Davies, J., \& Williment, J. (2008). Sport tourism: Grey sport tourists, all black and red experiences. Journal of Sport \& Tourism, 13(3), 221-242. http://dx.doi.org/10.1080/14775080802327144

Dees, W., Bennett, G., \& Villegas, J. (2008). Measuring the effectiveness of sponsorship of an elite intercollegiate football program. Sport Marketing Quarterly, 17(2), 79-89.

Dilys, M., \& Gargasas, A. (2014). Structural business model based on cooperation between sports organizations and sponsors. Engineering Economics, 25(1), 94-102. http://dx.doi.org/10.5755/j01.ee.25.1.2680

Drengner, J., Jahn, S., \& Zanger, C. (2011). Measuring event-brand congruence. Event Management, 15(1), $25-36$. http://dx.doi.org/10.3727/152599511X12990855575060 
Eagleman, A. N., \& Krohn, B. D. (2012). Sponsorship awareness, attitudes, and purchase intentions of Road Race Series participants. Sport Marketing Quarterly, 21(4), 210-220.

Falk, R. F., \& Miller, N. B. (1992). A primer for soft modeling. Ohio, USA: The University of Akron.

Farrelly, F. J., \& Quester, P. G. (2005). Examining important relationship quality constructs of the focal sponsorship exchange. Industrial Marketing Management, 34(3), 211-219. http://dx.doi.org/10.1016/j.indmarman.2004.09.003

Farrelly, F. J., Quester, P. G, \& Burton, R. (2006). Changes in sponsorship value: Competencies and capabilities of successful sponsorship relationships. Industrial Marketing Management, 35(8), $1016-1026$. http://dx.doi.org/10.1016/j.indmarman.2006.05.006

Flynn, L. R., \& Goldsmith, R. E. (1993). A causal model of consumer involvement: Replication and critique. Journal of Social Behavior \& Personality, 8(6), 129-142.

Fornell, C., \& Larcker, D. F. (1981). Evaluating structural equation models with unobservable variables and measurement error. Journal of Marketing Research, 18(1), 39-50.

Funk, D. C., Ridinger, L. L., \& Moorman, A. M. (2004). Exploring origins of involvement: Understanding the relationship between consumer motives and involvement with professional sport teams. Leisure Sciences, 26(1), 35-61. http://dx.doi.org/10.1080/01490400490272440

Gail, T., Nelson, C., Srzentic, T., \& King, R. (2007). Mere exposure and the endowment effect on consumer decision making. The Journal of Psychology, 141(2), 117-25. http://dx.doi.org/10.3200/JRLP.141.2.117-126

Goodhue, D. L., Lewis, W., \& Thompson, R. (2012). Does PLS have advantages for small sample size or non-normal data? MIS Q., 36(3), 981-1001.

Grohs, R. (2015). Drivers of brand image improvement in sports-event sponsorship. International Journal of Advertising, O(0), 1-30. http://doi.org/10.1080/02650487.2015.1083070

Grohs, R., \& Reisinger, H. (2005). Image transfer in sports sponsorships: An assessment of moderating effects. International Journal of Sports Marketing \& Sponsorship, 7(1), 42-48.

Grohs, R., \& Reisinger, H. (2014). Sponsorship effects on brand image: The role of exposure and activity involvement. Journal of Business Research, 67(5), 1018-1025. http://dx.doi.org/10.1016/j.jbusres.2013.08.008

Grohs, R., Wagner, U., \& Vsetecka, S. (2004). Assessing the effectiveness of sport sponsorships - an empirical examination. Schmalenbach Business Review, 56(2), 119-138.

Gwinner, K. P. (1997). A model of image creation and image transfer in event sponsorship. International Marketing Review, 14(2/3), 145. http://dx.doi.org/10.1108/02651339710170221

Gwinner, K. P., \& Eaton, J. (1999). Building brand image through event sponsorship: The role of image transfer. Journal of Advertising, 28(4), 47-57. http://dx.doi.org/10.1080/00913367.1999.10673595

Hahn, C., Johnson, M. D., Herrmann, A., \& Huber, F. (2002). Capturing customer heterogeneity using a finite mixture PLS approach. Schmalenbach Business Review, 54(3), 243-269.

Hair, J. F., Ringle, C. M., \& Sarstedt, M. (2011). Pls-Sem: Indeed a silver bullet. Journal of Marketing Theory and Practice, 19(2), 139-151 http://dx.doi.org/10.2753/MTP1069-6679190202

Hair, J. F., Sarstedt, M., Ringle, C., \& Mena, J. (2012). An assessment of the use of partial least squares structural equation modeling in marketing research. Journal of the Academy of Marketing Science, 40(3), 414-433. http://dx.doi.org/10.1007/s11747-011-0261-6

Heider, F. (1958). The psychology of interpersonal relations. New York: Wiley

Henseler, J., \& Chin, W. W. (2010). A comparison of approaches for the analysis of interaction effects between latent variables using partial least squares path modeling. Structural Equation Modeling: A Multidisciplinary Journal, 17(1), 82-109. http://dx.doi.org/10.1080/10705510903439003

Howat, G., \& Assaker, G. (2013). The hierarchical effects of perceived quality on perceived value, satisfaction, and loyalty: Empirical results from public, outdoor aquatic centers in Australia. Sport Management Review, 16(3), 268284. http://dx.doi.org/10.1016/j.smr.2012.10.001

Hur, Y., Ko, Y. J., \& Claussen, C. L. (2012). Determinants of using sports web portals: An empirical examination of the sport website acceptance model. International Journal of Sports Marketing \& Sponsorship, 13(3), 169-188.

Hutabarat, P., \& Gayatri, G. (2014). The influence of sponsor-event congruence in sponsorship of music festival. The South East Asian Journal of Management, 8(1), 47-64.

IEG (2014). Sponsorship spending growth slows in North America as marketers eye newer media and marketing options. Retrieved September 15, 2014, from http://www.sponsorship.com/IEGSR/2014/01/07/Sponsorship-SpendingGrowth-Slows-In-North-America.aspx

Jagre, E., Watson, J. J., \& Watson, J. G. (2001). Sponsorship and congruity theory: A theoretical framework for explaining consumer attitude and recall or event sponsorship. Advances in Consumer Research, 28(1), 439-445. 
Johan, G. V., \& Pham, M. T. (1999). Relatedness, prominence, and constructive sponsor identification. Journal of Marketing Research, 36(3), 299-312.

Johnston, M. A., \& Paulsen, N. (2011). The influence of club and sponsor images and club-sponsor congruence in the Australian Football League. International Journal of Sport Management \& Marketing, 9(1/2), $29-53$.

Keller, K. L. (1993). Conceptualizing, measuring, and managing customer-based brand equity. Journal of Marketing, $57(1), 1$.

Keller, K. L. (2003). Brand synthesis: The multidimensionality of brand knowledge. Journal of Consumer Research, 29(4), 595-600. http://dx.doi.org/10.1086/346254

Kim, K., \& Choi, S. M. (2007). Understanding the impacts of sponsorship-induced beliefs on corporate credibility and attitude toward the sponsor. In American Academy of Advertising. Conference. Proceedings (Online) (pp. 109113,115-118). Lubbock, United States: American Academy of Advertising.

Kim, Y. K., Ko, Y. J., \& James, J. (2011). The impact of relationship quality on attitude toward a sponsor. Journal of Business \& Industrial Marketing, 26(8), 566-576. http://dx.doi.org/10.1108/08858621111179840

Ko, Y. J., Kim, K., Claussen, C. L., \& Kim, T. H. (2008). The effects of sport involvement, sponsor awareness and corporate image on intention to purchase sponsors' products. International Journal of Sports Marketing \& Sponsorship, 9(2), 79-94.

Ko, Y. J., Kim, Y. K., Kim, M. K., \& Lee, J. H. (2010). The role of involvement and identification on event quality perceptions and satisfaction: A case of US Taekwondo Open. Asia Pacific Journal of Marketing and Logistics, 22(1), 25-39.

Lacey, R., Close, A. G., \& Finney, R. Z. (2010). The pivotal roles of product knowledge and corporate social responsibility in event sponsorship effectiveness. Journal of Business Research, 63(11), 1222-1228. http://dx.doi.org/10.1016/j.jbusres.2009.11.001

Lacey, R., Sneath, J. Z., Finney, Z. R., \& Close, A. G. (2007). The impact of repeat attendance on event sponsorship effects. Journal of Marketing Communications, 13(4), 243-255. http://dx.doi.org/10.1080/13527260701250752

Lardinoit, T., \& Quester, P. G. (2001). Attitudinal effects of combined sponsorship and sponsor's prominence on basketball in Europe. Journal of Advertising Research, 41(1), 48-58.

Levin, A. M., Joiner, C., \& Cameron, G. (2001). The impact of sports sponsorship on consumers' brand attitudes and recall: The case of NASCAR fans. Journal of Current Issues \& Research in Advertising, 23(2), 23-31. http://dx.doi.org/10.1080/10641734.2001.10505118

Llorens, J. M. (2011). La lealtad de los aficionados al fútbol. Una explicacion en base al valor de marca de su equipo y su nivel de implicacion. Universitat Jaume I, Castello de la Plana, Spain.

Lobo, A., Meyer, D., \& Chester, Y. (2014). Evaluating consumer response associated with sponsorship of major sporting events in Australia. Sport, Business and Management: An International Journal, 4(1), 52-70. http://dx.doi.org/10.1108/SBM-05-2011-0043

Macdougall, H. K., Nguyen, S. N., \& Karg, A. J. (2014). Game, Set, Match: An exploration of congruence in Australian disability sport sponsorship. Sport Management Review, 17(1), 78-89. http://dx.doi.org/10.1016/j.smr.2013.09.003

Madrigal, R. (2001). Social identity effects in a belief-attitude-intentions hierarchy: Implications for corporate sponsorship. Psychology \& Marketing, 18(2), 145-165. http://dx.doi.org/10.1002/1520-6793(200102)18:2<145 ::AID-MAR1003>3.0.CO;2-T

Mahalanobis, P. (1936). On the generalised distance in statistics (Vol. 2, pp. 49-55). Presented at the Proceedings National Institute of Science, India. Retrieved from http://ir.isical.ac.in/dspace/handle/1/1268

Mahony, D. F., Madrigal, R., \& Howard, D. (2000). Using the psychological commitment to team (PCT) scale to segment sport consumers based on loyalty. Sport Marketing Quarterly, 9(1), 15-25.

Martensen, A., Gronholdt, L., Bendtsen, L., \& Jensen, M. J. (2007). Application of a model for the effectiveness of event marketing. Journal of Advertising Research, 47(3), 283-301. http://dx.doi.org/10.2501/S0021849907070316

Maxwell, H., \& Lough, N. (2009). Signage vs. no signage: An analysis of sponsorship recognition in women's college basketball. Sport Marketing Quarterly, 18(4), 188-198.

Mazodier, M., \& Merunka, D. (2012). Achieving brand loyalty through sponsorship: the role of fit and self-congruity. Journal of the Academy of Marketing Science, 40(6), 807-820. http://dx.doi.org/10.1007/s11747-011-0285-y

Mazodier, M., \& Quester, P. (2014). The role of sponsorship fit for changing brand affect: A latent growth modeling approach. International Journal of Research in Marketing, 31(1), 16-29. http://dx.doi.org/10.1016/j.ijresmar.2013.08.004

McCracken, G. (1989). Who is the celebrity endorser? Cultural foundations of the endorsement process. Journal of Consumer Research, 16(3), 310-321. http://doi.org/10.1086/209217 
McDaniel, S. R. (1999). An investigation of match-up effects in sport sponsorship advertising: The implications of consumer advertising schemas. Psychology \& Marketing, 16(2), 163-184. http://dx.doi.org/10.1002/(SICI)15206793(199903)16:2<163::AID-MAR6>3.0.CO;2-Y

Meenaghan, J. A. (1983). Commercial sponsorship. European Journal of Marketing, 17(7), 5-73. http://dx.doi.org/10. 1108/EUM0000000004825

Meenaghan, T. (2001). Understanding sponsorship effects. Psychology \& Marketing, 18(2), 95-122. http://dx.doi.org/10.1002/1520-6793(200102)18:2<95::AID-MAR1001>3.0.CO;2-H

Mohr, L. A., \& Webb, D. J. (2005). The effects of corporate social responsibility and price on consumer responses. Journal of Consumer Affairs, 39(1), 121-147. http://dx.doi.org/10.1111/j.1745-6606.2005.00006.x

Navarro-Bailon, M. A. (2012). Strategic consistent messages in cross-tool campaigns: Effects on brand image and brand attitude. Journal of Marketing Communications, 18(3), 189-202. http://doi.org/10.1080/13527266.2011.567455

Novais, M. A., \& Arcodia, C. (2013). Measuring the effects of event sponsorship: Theoretical frameworks and image transfer models. Journal of Travel \& Tourism Marketing, 30(4), 308-334. http://dx.doi.org/10.1080/10548408. 2013.784149

Nunnally. J. C. (2010). Psychometric theory 3ed. McGraw-Hill Education (India) Pvt Limited.

Olson, E. L. (2010). Does sponsorship work in the same way in different sponsorship contexts? European Journal of Marketing, 44(1/2), 180-199. http://dx.doi.org/10.1108/03090561011008664

Osgood, C.E. \& Tannenbaum, P.H. (1955). The principle of congruity in the prediction of attitude change. Psychological Review, 62(4), 2-55. http://dx.doi.org/10.1037/h0048153

Pappu, R., \& Cornwell, T.B. (2014). Corporate sponsorship as an image platform: understanding the roles of relationship fit and sponsor-sponsee similarity. Academy of Marketing Science Journal, 42(5), 490-510. http://dx.doi.org/10. 1007/s11747-014-0373-X

Petty, R. E. \& Cacioppo, J. T. (1984). Source factors and the elaboration likelihood model of persuasion. Advances in Consumer Research, 11(1), 668-672.

Petty, R. E., Cacioppo, J. T., \& Schumann, D. (1983). Central and peripheral routes to advertising effectiveness: The moderating role of involvement. Journal of Consumer Research (pre-1986), 10(2), 135.

Pharr, J. R. \& Lough, N. L. (2012). Differentiation of social marketing and cause-related marketing in US professional sport. Sport Marketing Quarterly, 21(2), 91-103.

Poon, D. T. Y. \& Prendergast, G. (2006). A new framework for evaluating sponsorship opportunities. International Journal of Advertising, 25(4), 471-487. http://dx.doi.org/10.1080/02650487.2006.11072984

Pope, N. k. 1. \& Voges, K. e. (2000). The impact of sport sponsorship activities, corporate image, and prior use on consumer purchase intention. Sport Marketing Quarterly, 9(2), 96-102.

Pracejus, J. W. (2004). Seven psychological mechanisms through which sponsorship can influence consumers. In L. Kahle \& C. Riley, Sports Marketing and the Psychology of Marketing Communications. Mahwah, NJ: Lawrence Erlbaum Associates.

Pritchard, M. P., Funk, D. C., \& Alexandris, K. (2009). Barriers to repeat patronage: The impact of spectator constraints. European Journal of Marketing, 43(1/2), 169-187. http://dx.doi.org/10.1108/03090560910923283

Quester, P. \& Farrelly, F. (1998). Brand association and memory decay effects of sponsorship: The case of the Australian Formula One Grand Prix. Journal of Product \& Brand Management, 7(6), 539-556. http://dx.doi.org/10. $1108 / 10610429810244693$

Ramaswamy, V., DeSarbo, W. S., Reibstein, D. J., \& Robinson, W. T. (1993). An empirical pooling approach for estimating marketing mix elasticities with pims data. Marketing Science, 12(1), 103-124. http://dx.doi.org/10. $1287 / \mathrm{mksc} .12 .1 .103$

Rifon, N. J., Choi, S. M., Trimble, C. S., \& Li, H. (2004). Congruence effects in sponsorship: The mediating role of sponsor credibility and consumer attributions of sponsor motive. Journal of Advertising, 33(1), $29-42$. http://dx.doi.org/10.1080/00913367.2004.10639151

Ringle, C. M., Wende, S., \& Will, A. (2005). SmartPLS (Version 2.0). Hamburg: University of Hamburg.

Rodgers, S. (2004). The effects of sponsor relevance on consumer reactions to Internet sponsorships. Journal of Advertising, 32(4), 67-76. http://dx.doi.org/10.1080/00913367.2003.10639141

Roy, D. P. (2010). The impact of congruence in cause marketing campaigns for service firms. The Journal of Services Marketing, 24(3), 255-263. http://dx.doi.org/10.1108/08876041011040659

Roy, D. P. (2011). Impact of congruence in cause marketing campaigns for professional sport organizations. International Journal of Sport Management \& Marketing, 10(1/2), 21-34. http://dx.doi.org/10.1504/IJSMM.2011.043614

Roy, D. P., \& Cornwell, T. B. (2004). The effects of consumer knowledge on responses to event sponsorships. Psychology \& Marketing, 21(3), 185-207. http://dx.doi.org/10.1002/mar.20001 
Ruth, J. A., \& Simonin, B. L. (2003). Brought to you by brand A and brand B. Investigating multiple sponsors' influence on consumers' attitudes toward sponsored events. Journal of Advertising, 32(3), 19-30. http://dx.doi.org/10. 1080/00913367.2003.10639139

Sarstedt, M., \& Ringle, C. (2010). Treating unobserved heterogeneity in PLS path modeling: A comparison of FIMIX-PLS with different data analysis strategies. Journal of Applied Statistics, 37(8), 1299-1318. http://dx.doi.org/10. 1080/02664760903030213

Sarstedt, M., Becker, J. M., Ringle, C. M., \& Schwaiger, M. (2011). Uncovering and treating unobserved heterogeneity with FIMIX-PLS: Which model selection criterion provides an appropriate number of segments? Schmalenbach Business Review, 63(1), 34-62.

Scholl, H. J., \& Carlson, T. S. (2012). Professional sports teams on the Web: A comparative study employing the information management perspective. European Sport Management Quarterly, 12(2), 137-160. http://dx.doi.org/10. $1080 / 16184742.2012 .670254$

Shank, M. D., \& Beasley, F. M. (1998). Fan or fanatic: Refining a measure of sports involvement. Journal of Sport Behavior, 21(4), 435-443.

Smith, A., Graetz, B., \& Westerbeek, H. (2008). Sport sponsorship, team support and purchase intentions. Journal of Marketing Communications, 14(5), 387-404. http://dx.doi.org/10.1080/13527260701852557

Speed, R., \& Thompson, P. (2000). Determinants of sports sponsorship response. Journal of the Academy of Marketing Science, 28(2), 226-238. http://dx.doi.org/10.1177/0092070300282004

Stevens, S., \& Rosenberger, P. J. (2012). The influence of involvement, following sport and fan identification on fan loyalty: An Australian perspective. International Journal of Sports Marketing \& Sponsorship, 13(3), $220-234$.

Sutton, W., McDonald, M., Milne G., \& Cimperman, J. (1997). Creating and fostering fan identification in professional sports. Sport Marketing Quarterly, 6(1), 15-22.

Tenenhaus, M., Esposito Vinzi, V., Chatelin, Y. M., \& Lauro, C. (2005). PLS path modelling. Computational Statistics \& Data Analysis, 48(1), 159-205. http://dx.doi.org/10.1016/j.csda.2004.03.005

Tribou, G. (2011). Sponsorship: Associating image attributes with specific sports and particular teams. International Journal of Sports Marketing \& Sponsorship, 12(2), 138-152.

Vinzi, V. E., Chin, W. W., Henseler, J., \& Wang, H. (2010). Handbook of partial least squares concepts, methods and applications. Germany: Springer.

Wakefield, K. L., Becker-Olsen, K., \& Cornwell, T. B. (2007). I spy a sponsor: The effects of sponsorship level, prominence, relatedness, and cueing on recall accuracy. Journal of Advertising, 36(4), 61-74. http://dx.doi.org/ 10.2753/JOA0091-3367360405

Wang, M. C. H., Cheng, J. M. S., Purwanto, B. A., \& Erimurti, K. (2011). The determinants of the sports team sponsor's brand equity. International Journal of Market Research, 53(6), 811-829. http://dx.doi.org/10.2501/IJMR-53-6-000000

Wetzels, M., Odekerken-Schroder, G., \& Van Oppen, C. (2009). Using PLS path modeling for assessing hierarchical construct models: Guidelines and empirical illustration. MIS Quarterly, 33(1), 177-195.

Woisetschläger, D. M., \& Michaelis, M. (2012). Sponsorship congruence and brand image: A pre-post event analysis. European Journal of Marketing, 46(3/4), 509-523. http://dx.doi.org/10.1108/03090561211202585

Zaichkowsky, J. L. (1985). Measuring the involvement construct. Journal of Consumer Research, 12(3), 341-352.

The article has been reviewed.

Received in October 2014; accepted in February, 2016. 